\title{
The Influence of Brain Vitalization Exercise in Increasing Cognitive Functions For Elderly in Lingkar Barat Public Health Center Bengkulu 2018
}

\author{
Sariman Pardosi* Nehru Nugroho \\ Nursing Department of Health Polytechnic The Ministry of Health Bengkulu
}

\begin{abstract}
Over time elderly experience the decline in various functions of organs, one of which is a decrease in cognitive function. One of the exercises for the elderly to maintain brain fitness is brain vitalization exercise. This study aims to investigate the influence of brain vitalization exercise in increasing cognitive functions for the elderly. The design used was a quasi-experiment with pre-test and post-test with control group design. this study selected the sample through purposive sampling with a total of 18 samples for each group. In the prior of the study, the samples were observed and the observation was retaken to the samples after the intervention. The analysis used was parametric using paired T-test and independent T-test in the intervention group, and parametric analysis using the Wilcoxon and Mann Whitney tests in the control group. The results of the study comparing postintervention and post control showed that the average MMSE score after being given brain vitalization exercise no significant difference $(p=0.007)$. It can be concluded that there is no effect of brain vitalization exercise between the intervention and control groups in improving cognitive function for elderly in Lingkar Barat Public Health Center of Bengkulu city.
\end{abstract}

Keywords: brain vitalization exercise, cognitive function

DOI: $10.7176 /$ RHSS/9-10-05

Publication date:May $31^{\text {st }} 2019$

\section{Introduction}

One indicator of successful development is the increasing life expectancy of the population. With increasing population life expectancy, the number of elderly people continues to increase from year to year (Ministry of Health Strategic Plan, 2015). Older people who are still healthy and productive will be more useful for themselves, their families and their social environment.

Over time, the elderly experience a decline in various functions of the body's organs. Besides, the lack of activity and nutrient intake, pollution, and free radicals greatly affect the decline in functions of organs for elderly (Sulianti, 2009).

Regardless of the function decline physiologically, the thing that needs to be considered is Quality of Life (quality of life) for the elderly. Quality of life is the ability of a person to carry out his life both social and mental and to gain prosperity level which not only concern illness resistance.

The decline of cognitive function in mild symptoms is easy to recognize with memory loss and in severe symptoms causes senility. This condition is often considered a normal problem and naturally happens to the elderly. Indeed, the decline in cognitive abilities characterized by memory loss is one of the early symptoms of senility (Nugroho,2018)

Exercises or games which require concentration or attention, orientation (place, time, and situation) and memory can increase the work potential of the brain. The exercise should aim to increase general physical fitness through brain exercises (Brain Vitalization Exercise).

Brain vitalization exercise is an activity that stimulates intellectuals which aims to maintain brain health by exercising (Markam, 2006). The benefits of vitalization exercise in the brain is to improve the ability of alertness, concentration, memory and executive capacities for the elderly.

The results of the initial survey in Lingkar Barat Public Health Center (Puskesmas Lingkar Barat) involved 10 elderly measured for cognitive function. It was found that 7 people experienced cognitive function at a moderate level, while 3 elderly cognitive functions at a mild level (Survey in West Rim Health Center, 2018).

Based on the description above, the authors intended to study and investigate deeply through research with the title of the influence of brain vitalization exercises in improving cognitive function for the elderly group in the area Puskesmas Lingkar Barat.

\section{Method}

The study was a quasi-experimental research with the research design of pre-test and post-test with control group design. the state of samples before the intervention was observed and the observation was retaken to the samples after the intervention. (Nursalam, 2008).

The research site was in the working area of Lingkar Barat Public Health Center Bengkulu city and it was 
done in July - November 2018.

The samples were selected through purposive sampling with a sample of 18 respondents for each group and total samples of 36 respondents. The samples are respondents who meet the inclusion criteria, namely: age $\geq 55$ years, good hearing and sight, no physical disability that interferes daily activities, and respondents are needed to do the exercise program regularly.

The instrument used in this study was in the form of a Mini-Mental State Examination (MMSE) to measure cognitive function in the pre-intervention and post-intervention stage in the elderly.

Then 6 instructors were trained to lead the gymnastics exercise for the elderly. They were also taught to measure MMSE with special instruments prepared by the researcher. brain vitalization exercises were done once a week for 6 consecutive weeks, accompanied by instructors to ensure the elderly can carry out the exercise in accordance with standard operating procedures (SOP).

\section{Result}

\section{Univariate Analysis}

It is used to see the mean, univariate analysis is used to see the characteristics of respondents and the average cognitive value of respondents in the control and intervention groups. The univariate analysis resulted in mean, standard deviation, minimum-maximum value, percentage, and 95\% CI for the mean before and after the intervention.

Table 1 Age-based Respondents Distribution in Lingkar Barat Public Health Center Bengkulu City 2018

\begin{tabular}{llll}
\hline Variables & Group & & P Value \\
& Intervention & Control & \\
Mean & 65.67 & 61.50 & 0.19 \\
Median & 65.00 & 61.00 & \\
SD & 8.253 & 3.974 & \\
Min - Max & $54-85$ & $56-74$ & \\
95\% CI for mean & $61.56-69.77$ & $59.52-63.48$ & \\
\hline
\end{tabular}

According to table 1 it shows that the average characteristics of respondents in the intervention group were 65.67 years old, median 65 years, up to 8,253 , the youngest respondents was 54 years and the oldest respondents was 85 years. From the interval estimation, it can be concluded that $95 \%$ respondents in intervention group was 61.56 - 69.77 years. Average respondents' characteristics in the control group were 61.50 years, median 61 years, up to 3,974 , the youngest respondents was 56 years and the oldest respondents was 74 years. From the interval estimation it can be concluded that $95 \%$ respondents in control group was $59.52-63.48$ years. Homogeneity test shows that there was no difference in age between intervention group and control group with $p$ value $>0.05$ at $\alpha$ $=0.05$ (equivalent).

Table 2 Respondents Distribution based on Education Background, Sex, and Health Problem in Lingkar Barat Public Health Center Bengkulu City 2018

\begin{tabular}{|c|c|c|c|c|c|}
\hline \multirow[t]{2}{*}{ Characteristics } & \multicolumn{2}{|l|}{ Intervention } & \multicolumn{2}{|l|}{ Control } & \multirow{2}{*}{$\begin{array}{l}\mathrm{P} \\
\text { value }\end{array}$} \\
\hline & frequencies & percentage & frequencies & percentage & \\
\hline \multicolumn{6}{|l|}{ Sex } \\
\hline Male & 5 & $27.8 \%$ & 1 & $5.6 \%$ & \multirow[t]{2}{*}{0.77} \\
\hline Female & 13 & $72.2 \%$ & 17 & $94.4 \%$ & \\
\hline Total & 18 & $100 \%$ & 18 & $100 \%$ & \\
\hline \multicolumn{6}{|l|}{ Education Background } \\
\hline Low & 8 & $44.4 \%$ & 4 & $22.2 \%$ & \multirow{3}{*}{0.12} \\
\hline Moderate & 8 & $44.4 \%$ & 14 & $77.8 \%$ & \\
\hline High & 2 & $11.1 \%$ & 0 & 0 & \\
\hline Total & 18 & $100 \%$ & 18 & $100 \%$ & \\
\hline \multicolumn{6}{|l|}{ Health Problems } \\
\hline Gout & 1 & $5.6 \%$ & 3 & $16.7 \%$ & \multirow{7}{*}{0.17} \\
\hline Diabetes & 2 & $11.1 \%$ & 0 & 0 & \\
\hline hypertension & 6 & $33.4 \%$ & 6 & $33.3 \%$ & \\
\hline Gastritis & 1 & $5.6 \%$ & 0 & 0 & \\
\hline Vertigo & 1 & $5.6 \%$ & 0 & 0 & \\
\hline Cardiac problem & 0 & 0 & 3 & $16.7 \%$ & \\
\hline No Health Problems & 7 & $38.9 \%$ & 6 & $33.3 \%$ & \\
\hline Total & 18 & $100 \%$ & 18 & $100 \%$ & \\
\hline
\end{tabular}

According to table 2 we find data that more than half of the respondents were female, $72.2 \%$ in the 
intervention group and $60.0 \%$ in the control group of the 18 total respondents in each group.

Respondents in intervention group with low level background education were $44.4 \%$, moderate education background were $44.4 \%$, and higher education background were $11.1 \%$. In control group, respondents with low education background were $22.2 \%$ and respondents higher education background were $77.8 \%$.

Respondents in intervention group with gout were $5.6 \%$, diabetes were $11.1 \%$, hypertension were $33.4 \%$, gastritis were $5.6 \%$, vertigo were $5.6 \%$. Respondents in control group with gout were $16.7 \%$, hypertension were $33.3 \%$, cardiac problem $16.7 \%$.

Homogeneity test shows that there were no differences in sex, education background and health problems between intervention group and control group with a $p$ value $>0.05$ at $\alpha=0.05$ (equivalent).

Table 3 Elderly MMSE Average Score in Pre and Post Intervention Stage of

Brain Vitalization Exercise in Lingkar Barat Public Health Center, Bengkulu City 2018

\begin{tabular}{lccccccc}
\hline Variables & $\mathrm{N}$ & Mean & Median & $\mathrm{Sd}$ & Min - Max & $95 \%$ Ci For Mean & P Value \\
\hline Pre & & & & & & & \\
Intervention & 18 & 21.06 & 21.50 & 2.461 & $17-25$ & $19.83-22.28$ & 0.024 \\
Control & 18 & 24.72 & 25.00 & 1.487 & $21-26$ & $23.98-25.46$ & \\
\hline Post & & & & & & & \\
Intervention & 18 & 25.72 & 26.00 & 1.776 & $22-28$ & $24.84-26.61$ & 0.007 \\
Control & 18 & 26.33 & 26.50 & 0.840 & $24-27$ & $25.92-26.75$ & \\
\hline
\end{tabular}

According to table 3, the results of data analysis in the intervention group showed an average MMSE score in the elderly before brain vitalization exercises was 21.06 with a median of 21.50 , standard deviation 2,461 . the lowest score of MMSE in before brain vitalization exercise was 17 and the highest score was 25 . From the interval estimation, it can be concluded that $95 \%$ of average MSSE score in the elderly before brain vitalization exercises was between 19.83 to 22.28 .

While the average MMSE score after brain vitalization exercises from the analysis of the results was 25.72, with a median of 26.00 , the standard deviation of 1,776 . the lowest MMSE score after being brain vitalization exercise was 22 and the highest score was 28 . From the interval estimation, it can be concluded that $95 \%$ of average MMSE score in the elderly after brain vitalization exercises was between 24.84 to 26.61 .

The results of data analysis in control group showed an average MMSE score in pre-elderly of 24.72 with a median of 25.00 , a standard deviation of 1,467, the lowest score of MSSE in the pre-elderly was 21 and the highest score was 26 . From the interval estimation, it was concluded that $95 \%$ MMSE score in pre-elderly was between 23.98 to 25.46 .

While the average MMSE post score from the analysis of the results was 26.50 , with a median of 26.50 , a standard deviation of 0.840 . The lowest score of MMSE in the post-elderly was 24 and the highest score was 27 . From the interval estimation, it can be concluded that $95 \%$ of average MMSE score in post-elderly was between 25.92 to 26.75

\section{Bivariate Analysis}

Bivariate analysis was carried out to determine the differences in the cognitive function of the elderly before and after being given brain vitalization exercises in the intervention group, the differences in cognitive function of the elderly before and after in control group, and to see the effect of brain vitalization exercises in intervention and control groups. From table 4, the data shows that the difference in the average MMSE score in the intervention group before and after being given exercise/brain vitalization training is 2.90 . Statistical results showed $p=0.0001<0.05$, meaning that there were significant differences in cognitive function in the elderly before and after being given exercise/brain vitalization exercises.

Table 4 Average Discrepancy of MMSE Score between Intervention and Control Groups in Pre and Post Stage of Brain Vitalization Exercise in Lingkar Barat Public Health Center Bengkulu City 2018

\begin{tabular}{lccc}
\hline Variables & $\mathrm{N}$ & $\Delta$ Mean & P value \\
\hline $\begin{array}{l}\text { Intervention } \\
\text { Post - Pre }\end{array}$ & 18 & 4.667 & 0.0001 \\
\hline $\begin{array}{l}\text { Control } \\
\text { Post - Pre }\end{array}$ & 18 & 1.61 & 0.003 \\
\hline
\end{tabular}

According to table 4, the data shows that the discrepancy in the average MMSE score in the intervention group before and after brain vitalization exercise of 2.90. Statistical results showed $p=0.0001<0.05$, meaning that there were significant differences in cognitive function in the elderly before and after brain vitalization exercises.

In the control group, the discrepancy in the average MMSE score before and after was 1.61. The statistical test results showed $p=0.003<0.05$, meaning that there were significant differences in the cognitive function of the elderly in the control group. 
Table 5 The Difference of MMSE Score in Elderly between Intervention and Control Groups in Pre and Post Stage of Brain Vitalization Exercise in Lingkar Barat Public Health Center Bengkulu City 2018

\begin{tabular}{lrccc}
\hline Variables & $\mathrm{N}$ & Mean & $\Delta$ Mean & P value \\
\hline Post Intervention & 18 & 25.72 & & \\
Post Control & 18 & 26.33 & 0.61 & 0.007
\end{tabular}

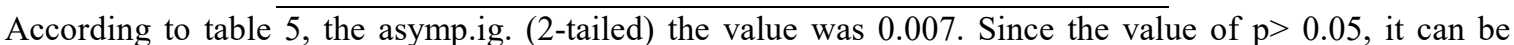
concluded that there was no significant difference in elderly MMSE scores between the intervention group and the control group. It can be concluded that there was no effect of brain vitalization exercises between the intervention and control groups in improving the cognitive function of the elderly in Lingkar Barat Public Health Center Bengkulu City.

\section{Discussion}

\subsection{Respondents characteristics}

The results on 36 respondents divided into two groups show that the elderly who did gymnastics were mostly female in the intervention group (72.2\%) and control group (94.4\%), age range between 54 to 85 years with average age of respondents in intervention group was 65.67 years while in control group was 61.50 years. This shows that age is not an obstacle for the elderly to stay active in physical activities.

In general, the majority of respondents had a moderate education background in the intervention group $(4.4 \%)$ and the control group (77.8\%). The influence of education background of the elderly can indirectly affect their cognitive function. The level of education has an influence on cognitive functions. Education affects brain capacity and impacts on the cognitive test (Farmer, 1999).

Based on health problems experienced by respondents most of the respondents in the control group (33.3\%) and interventions $(33.4 \%)$ had hypertension problems. The risk of hypertension increases with age, especially in men over 45 years and in women over 55 years of age (Muhammadun, 2010).

In the elderly, there is a change in the structure and function of blood vessels. The nature of the elasticity of blood vessels decreases and the stiffness in the walls of the arteries becomes smaller so that the development of blood vessels becomes disrupted (Potter \& Perry 2005).

\subsection{Elderly cognitive function in the working area of Lingkar Barat Public Health Center Bengkulu City} After the elderly did brain vitalization exercises once a week for 6 consecutive weeks, the results of the average MMSE score of the respondents' intervention group were 21.06 before brain vitalization exercises and 25.72 after brain vitalization exercises. While in the control group, the results of the analysis of the average MMSE score were 24.72 before the intervention and 26.33 after the intervention.

Based on these results it can be seen that the picture of the cognitive function of the elderly after doing brain vitalization exercises is greater than before brain vitalization exercises. The study obtained $\mathrm{P}$ value of the intervention group with a significant of 0,0001 and the control group $\mathrm{P}$ value was 0.003 . With a $\mathrm{P}$ value of $<0.05$, it was concluded that there was a significant difference in cognitive function in the elderly before and after the intervention.

\subsection{The Influence of brain vitalization exercises on the elderly in the working area of Lingkar Barat Public Helath Center Bengkulu}

According to the research that concerned to determine the differences in cognitive function of the elderly in the intervention group and control group after doing brain vitalization exercise, it was obtained a significant value of 0.007. since the value of $\mathrm{P}$ value $>0.05$, it means there was no significant difference between the intervention group and control group after brain vitalization exercise. It was concluded that there was no influence of brain vitalization exercise in improving the cognitive function of the elderly group in the working area of Lingkar Barat Public Health Center, Bengkulu City.

The researcher argues that there was no significant difference between the intervention group and the control group because Lingkar Barat Public Health Center held gymnastic activities twice a week that was followed by all the elderly. Most elderly from both intervention and control groups actively participated in this exercise which was held every Friday and Tuesday consisting of Lansia (elderly) gymnastics, Germas (healthy community movement) gymnastics, and Diabetic gymnastics. So that even though they do not take part in exercise brain vitalization exercise, the elderly in the control group still continue to exercise.

The physiological benefits for the elderly are to help to regulate blood sugar levels, stimulate adrenaline and nor-adrenaline, improve sleep quality and quantity. Furthermore, Kusumo Putro (2003) stated that there is an increase in the potential and resources of the brain, what is needed is physical fitness and brain fitness.

Brain vitalization exercise is a physical exercise that concerns on human brain fitness sustainability, this exercise is designed to combine the body movement, breathing, and cognitive center (memory and imagination). The series of movements in brain vitality exercise not only involve kinetic centers of certain muscles in the brain 
with corpus callosum but also involve the higher center parts in the brain.

The measurement of MMSE can be done every 6 weeks since the neuron tissues adaptation takes 4-6 weeks where physical exercise and cognitive function gets interconnected through the muscle contraction, and it could affect the brain through spindle muscle channel. The stimulus in Golgi tendon organ will be passed through to the nerve system center via neurons. These neurons receive the sensory information from the peripheral, visual system, vestibular system, musculo-sceletal, proprioseptic, and others where it would be then processed and integrated in all level of nerve system (Leni,2013)

\section{Conclusion}

The characteristics of female respondents were $72.2 \%$ in the intervention group and $60,0 \%$ in the control group. Respondents with Low education background were $44.4 \%$ in the intervention group and $22.2 \%$ in the control group. Respondents with hypertension were $33.4 \%$ in the intervention group and $33.3 \%$ in the control group.

The difference in MMSE score between intervention and control groups indicates p-value $<0,005$ which refers to a significant difference in cognitive value on the elderly before and after brain vitalization exercise.

The result analysis done to post value between intervention and control shows $p$ value $0.007>0.005$ which indicate the difference in MMSE score between intervention and control groups after brain vitalization exercise. It can be concluded that there is no influence of brain vitalization exercise in the increased cognitive function in the elderly in the working area of Lingkar Barat Public Health Center, Bengkulu city.

\section{References}

A Parellangi, KK Dharma.(2019). The intervention of brain gym in increasing the quality of life on the elderly. Asian Community Health Nursing.vol.1(11);p.30-35

Kementerian Kesehatan Republik Indonesia. (2015). Rencana Strategis Kementerian Kesehatan Republik Indonesia Tahun 2015-2019. Jakarta : Setjend Kemenkes RI

Kusumoputro, S., Sidiarto, L. D., Sarmino, Munir, R., Nugroho, W. (2003). Kiat Panjang Umur dengan Gerak dan Latih Otak, Jakarta: UI Press.

Leni,ASM.(2013). Pengaruh Senam Otak Terhadap Daya Ingat Pada Wanita Post Menopause. Retrieved from https://publikasiilmiah.ums.ac.id/bitstream/handle/11617/3341/2.\%20ARI\%20SEPTI\%20MEI\%20LENI.pd f;sequence $=1$

Markam, S., Mayza, A., Pujiastuti, H., Erdat, M. S., Suwardhana, Solichien, A.( 2006). Latihan Vitalisasi Otak. Jakarta: Grasindo.

Muhammadun, (2010). Hidup Bersama Hipertensi. In Books : Yogjakarta

Nursalam, (2008). Konsep dan Penerapan Metodologi Penelitian Ilmu Keperawatan : Jakarta: Salemba Medik

Ocampo,Jose,Valera,Leonora,Ocampo, Laura.(2017).Effectiveness of Brain Gym Activities in Enhancing Writing Performance of Grade 1 Pupils. Sosio Humanika Jurnal Pendidikan Sains Sosial dan Kemanusiaan.Vol 10(2);p.179-190

PA Potter, AG Perry. (2005). Buku ajar fundamental keperawatan: konsep, proses, dan praktik- Jakarta: EGC

Prasaja, Maharso Adi, Nugroho. (2018) Pengaruh Training Kognitif Terhadap Kemampuan Kognitif Pada Lansia di Desa Sobokerto Kecamatan Ngemplak Boyolali. Jurnal Keterapian Fisik. Vol 3(2).p.100-106. 